\title{
Breakpoint Cluster Region Protein
}

National Cancer Institute

\section{Source}

National Cancer Institute. Breakpoint Cluster Region Protein. NCI Thesaurus. Code

C17477.

Breakpoint cluster region protein (1271 aa, $\sim 143 \mathrm{kDa}$ ) is encoded by the human BCR gene. This protein is involved in both serine/threonine-protein kinase and GT Paseactivating protein activities. 